\title{
Responses in plants exposed to dust pollution
}

\begin{abstract}
In context to the present scenario of urban pollution, there is a growing need for changing the approach of planting trees and other plant species. Addition of the ornamental plants having pollution mitigating ability in the landscape-map may provide the twin-rationale of making the cities green and pollution-controlled. A proper planting-plan may generate healthy and colorful living. The importance of trees in metropolitan environment is now heavily accepted that they too purify the air pollution from the dust-particulates. The rich-biodiversity of India tenders a broad assortment of options to try and reconsider our dust-laden cities and towns. This article describes the way the dust particles affect the plants and trees, and the response of the plants to the particulate-exposure.
\end{abstract}

Volume I Issue 2 - 2017

\section{Rupnarayan Sett}

Division of Genetics and Plant Propagation, India

Correspondence: Rupnarayan Sett, Division of Genetics and Plant Propagation, Tropical Forest Research Institute (ICFRE, MoEFCC), Mandla Road, PO RFRC 482021, Jabalpur, Madhya Pradesh, India, Email ruppuran200I@yahoo.co.in

Received: September 07, 2017 | Published: November 08, 2017

Keywords: dust pollution, particulate matters, plant response

\section{Introduction}

Dust particles form a major part of air pollutants arising due to industrial processes and pose serious threat to the ecosystem. In India $30-35 \%$ of air pollutants comprises of dust particles. Activities such as coal mining, quarrying, stone crushing, thermal power plants, cement industries etc., adds huge quantities of dust to the environment. The current scenario of large scale deforestation; destruction of biota and other ecosystem components are being attributed to be the effect of dust pollution. ${ }^{1}$ Aerosols being small enough to be suspended in air have an affinity to adhere to the solid surface coming in contact with it. When the air current passes through a tree, some portion of the dust particle adhere to the upper and lower portion of the leaves, some of these are bounced back or deposited elsewhere depending upon the size and character of the particle, wind velocity and the surface area of deposition. ${ }^{2}$ After deposition dust particles have a tendency to stick to the leaf surfaces for a definite period of time till they get washed off with rain or shredding of the leaf itself. Particle having size lesser than diameter of stomata apertures directly enters the sub-stomatal cavity and comes in contact with the spongy parenchyma of the leaf tissue, larger particles gets access into the leaf interior by getting dissolved in water and carbonic acid discharged by the stomata itself. Plants grasp the dust and loam of topsoil; the soil-inhabitant tiny plants also reduce air-pollutants and break or degrade many poisonous chemicals those go into the soil.

\section{Factors affecting dust pollution}

\section{Foliar morphology and anatomy}

Capacity of leaves as dust receptors depends on surface geometry, epidermal and cuticular features of leaves and height \& canopy of the tree. ${ }^{4-6}$ Phyllotaxy, leaf orientation and sessile or semi sessile nature of leaves also plays an important role by providing maximum area for dust deposition keeping leaves in a horizontal direction. ${ }^{2}$ Nearly natural and vertical orientation of leaves results in lesser dust deposition as in case of Eucalyptus. ${ }^{7}$ Simple leaves have been shown to be better dust collectors than the trees having compound leaves.

\section{Mineral composition of dust}

In a study conducted by Chatson et al., ${ }^{7}$ it was revealed that both mineralogy and particle size are much important factors that controls the biochemical reactions within the plants. Fine carbon black resulted in a leaf temperature increase of about 10 times that of coarse dust in the study. It has also been demonstrated that at even very lower concentrations fine dust particles are capable of causing effects where as in case of coarse particles higher doses are required. As the chemical nature of the particulates is diverse, a series of synergistic reactions may occur among these particles, which in turn, can affect the physiological functions of the plant in number of ways. If dust particles are inert then it induces some mechanical injury or else if it contains certain soluble toxicants, it may produce necrotic spotting. ${ }^{8}$ In presence of moisture, it solidifies into hard adherent crust, which can damage plant tissue and inhibit growth. ${ }^{9}$ Growth inhibition may be due to screening of light, plugging of stomata openings and direct injury to plant tissue by the chemical reactions of dust particles on leaf surfaces..$^{910}$ As a result decrease in rate of $\mathrm{CO}_{2}$ exchange, ${ }^{11}$ carbon assimilation, ${ }^{12}$ transpiration ${ }^{13}$ and net photosynthesis ${ }^{14,15}$ is observed. The exact amount of dust causing such effect is not known but is somewhat over $1.0 \mathrm{~g} / \mathrm{m}^{2} /$ day, ${ }^{16}$ Figure 1 .

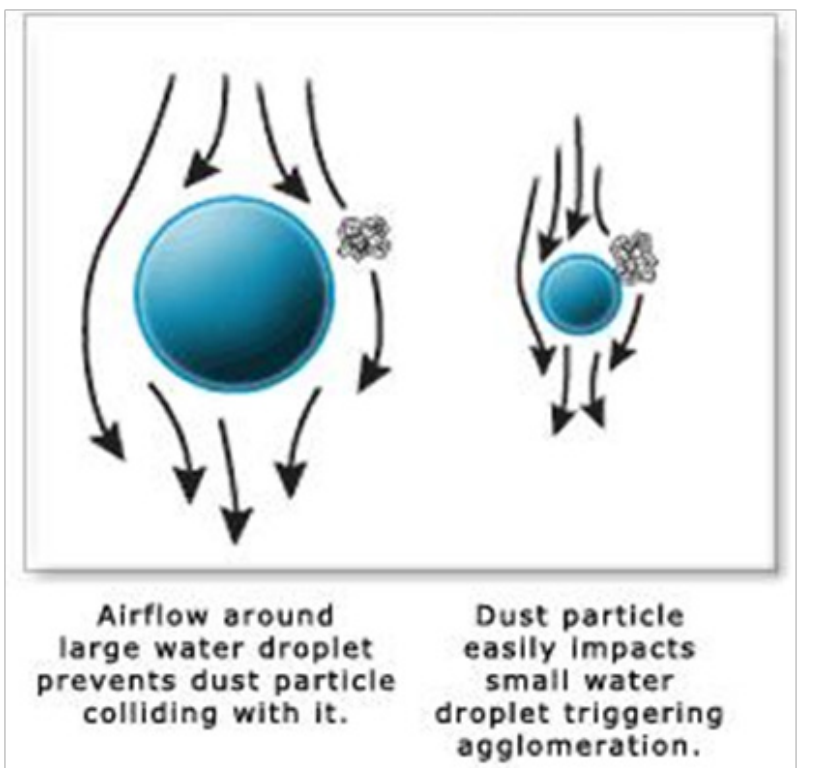

Figure I The exact amount of dust causing such effect is not known but is somewhat over $1.0 \mathrm{~g} / \mathrm{m}^{2} /$ day. 


\section{Dust induced effects on chlorophyll}

Reductions in Chlorophyll due to dust deposition have also been observed by many coworkers. ${ }^{17-23}$ Dust deposition on leaf surfaces reduces synthesis of chlorophyll-a due to shedding effects. Thus increase in dust deposition and the corresponding chlorophyll degradation can be positively correlated. Alkaline conditions prevailing due to solubility of dust particulates in the cell sap are responsible for chlorophyll degradation and reduced photosynthetic activity. ${ }^{17}$ The hydration process of crust formation due to dust deposition on leaf of dusted plants, releases $\mathrm{Ca}(\mathrm{OH})_{2}$ (highly alkaline). This penetrates through stomata and injures the cell beneath and causes partial denaturation of chloroplast and subsequent decrease in pigments in the cells of damaged leaves. ${ }^{24}$ It has been proposed in the above study that there are possibilities of degradation of enzymes responsible for chlorophyll biosynthesis. ${ }^{10}$ Alkaline dust deposited on leaf surfaces can also result in leaf chlorosis and death of leaf tissue by combination of thick crust and alkaline toxicity produced in wet weather Figure 2. Deposition may increase the soil $\mathrm{p}^{\mathrm{H}}$ to levels that are adverse to crop growth, ${ }^{20}$ Figure 3 .

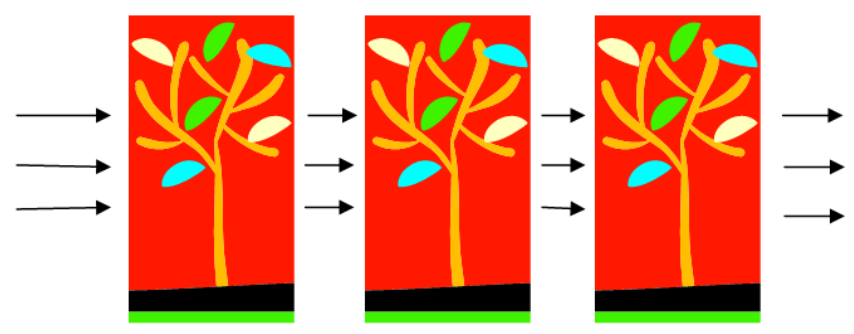

Figure 2 Good filtering effects of loose plantations.

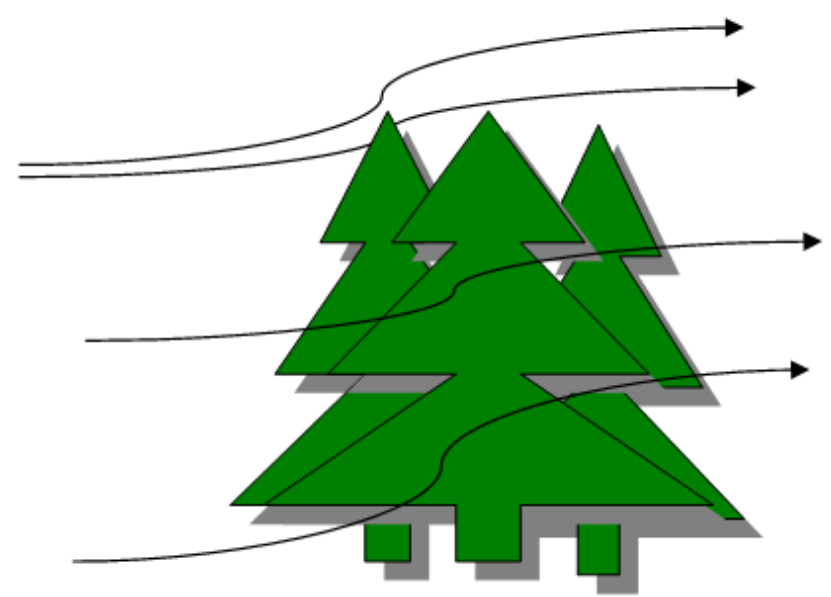

Figure 3 Small filtering effects of the thick plantations.

\section{Effects on stomata}

Dust deposition also result in stomata clogging, ${ }^{25}$ which results in decreased rate of carbon dioxide exchange,,$^{11}$ carbon assimilation, ${ }^{12}$ transpiration, ${ }^{13}$ and therefore net photosynthesis. ${ }^{15}$ Rajchidambaram et al. (1980) observed clogging of stomata, loss of one or both guard cells or total destruction of stomata apparatus caused by cement dust pollution in all the five species of flowering plants studied by them. Yunus et al. ${ }^{26}$ noticed a conspicuous increase in frequency of stomata, percentage of abnormal stomata, larger stomatal openings and conspicuous circular striations in polluted population of Ricinus communis L. Leaves of Syzygium cumini L, showed marked decrease in epidermal cell size, increase in number of epidermal cells and stomata, necrotic lesions and death of epidermal cells. ${ }^{27-29} \mathrm{Few}$ common avenue plants as $A$. indica and $P$. longifolia were found with dust particles embedded in the wax crust of the leaves. Cuticles were disorganized and broken at the outer stomata ledge. Papillae lost their identity completely. Peri-stomata rim was not well defined. The stomata ledges were entirely broken and large particles of dust and debris were present on the injured cuticular surfaces. Shamnughavel ${ }^{30}$ observed abnormalities such as stomata with single guard cell, with 3-5 subsidiary cells and giant stomata. All the above injury focuses on dust induced mechanical stress on plants.

\section{Effects on metabolites}

Protein and starch content of the leaves which are very often being used for monitoring of air pollution, are also reduced on exposure to dusty environment. ${ }^{15-31}$ According to Borka, ${ }^{12}$ starch reduction is due to clogged stomata that might have inhibited the phosphorylation of sugars and consequently translocation from the assimilative leaves because of lowering of transpiration and hence over heating of leaves. The most striking feature is the accumulation proline which plays a protective role in stress condition. ${ }^{32}$ This acts as a storage compound for ' $\mathrm{C}$ ' and ' $\mathrm{N}$ ' and is utilized to build new proteins when protein synthesis is inhibited during stress condition. ${ }^{33}$

\section{Leaf as a dust monitor}

Use of leaves for monitoring of dust pollution, using various morphological considerations has recently been worked out. ${ }^{34-39}$ The dust clearing capacity of trees has been demonstrated in England and Soviet Union. ${ }^{2}$ In the Hyde Park, a green area of 1 Sq. Mile in center of London, an average reduction in the smoke concentration of $27 \%$ was found in comparison with non-green area surrounding it. The vegetative dust filters were arranged in descending order of dust filtration. It was calculated that 300 Poplars which are the poorest dust collectors, spread over 2.5 acres, would filter out 0.375 tons of dust during the leaf-bearing season. These selective responses of leaves against dust can be used for monitoring of dust pollution. ${ }^{40}$ It is evident from many findings that cuticular and epidermal traits of the leaves respond quantitatively rather than qualitatively to dust pollution and can be used as bio-indicator of pollution levels..$^{8-44}$ In Mimusops elengi it was observed that the trichomes were completely absent in the non-polluted region but in the polluted region unicellular trichomes were developed in the abaxial surface and their development were maximum at epidermal cells near stomata. Rangarajan et al. ${ }^{45}$ reported increase in the frequency of the trichomes on the adaxial side of the leaves of the ornamental plants. This suggests that trichomes acts as protective cover against atmospheric pollutants especially particulate matter, so as they did not get entrance through opening of stomata..$^{8-41}$ Leaves of trees dusted with particulate matter showed significant reduction in protein and nitrogen content with corresponding leaf fall in deciduous species. ${ }^{15}$ Dust deposition on leaves results in reduction in the photosynthetic leaf area resulting in reduced photosynthesis. Reduction in number of flower and yield in black gram ${ }^{31}$ and other flowering plants have been noticed due to dust pollution. ${ }^{10}$ Borka $^{12}$ is of the opinion that under the effect of dust the acidic secretion of stigma turned into alkaline, a condition that is unfavorable for pollen germination, which leads to poor fertilization and yield. Field transact studies have highlighted adverse plant response to dust. Average yield loss in paddy attributable to the cement dust polluted environment 
was approximately $20 \%{ }^{46}$ Singh et al. (1990) investigated Oryza sativa growing at different locations around a cement factory and found that vegetative and reproductive part accumulated significantly lower biomass (by 33 and 60\% respectively) at sites $1 \mathrm{~km}$ from the factory receiving high dust loads. Impact of flyash on characteristics of grains of wheat was demonstrated by lower values of grains per spike, weight and volume, moisture, protein, total ash, fat, crude fiber and calorific value in a study conducted by Pandey et al. (2001).

Tree species such as peach, cherry and citrus have exhibited signs of air pollution induced injury with inhibited or shortened flowering period, early leaf abscission and premature dropping of fruits. ${ }^{46}$ Development of red and brown necrotic lesions and a thick layer of black dust on leaf surfaces along with delayed sprouting and accelerated senescence was observed in the industrial city of southeast China with annual daily mean concentration of SPM of about $320 \mu \mathrm{g} / \mathrm{m}^{3} \cdot{ }^{46}$ Dust from cement kiln showed depressive effect on the mitotic index of Vicia faba and it was inversely proportional to the concentrations of dust, while the frequency of abnormality during mitosis was directly proportional. Chromosomal breakage and chromosome bridges were predominantly recorded at metaphase and anaphase respectively. In view of the cytotoxic effects of cement kiln dust, it can also act as a mutagen ${ }^{47}$ These features as a result of dust deposition on foliar parts can be used as bio-indicators of dust pollution.

The characteristics of plants for effective pollution control have jotted down by Kumar et al. ${ }^{48}$ as follows:

a. Tolerance to specific conditions or alternatively wide adaptability to eco-physiological conditions.

b. Rapid growth.

c. Capacity to endure water stress and climate extremes after initial establishment.

d. Differences in height and growth habits.

e. Pleasing appearances.

f. Providing shade.

g. Large bio-mass and leaves number to provide fodder and fuel.

h. Ability of fixing atmospheric Nitrogen.

i. Improving waste lands.

Trees having thick and fleshy leaves with petioles flexible and capacity to withstand vibration are suitable.

Heavier branches and trunk of the trees also deflect or refract the sound waves.

\section{Discussion}

Dust pollution is of localized importance near roads, quarries, cement works, and other industrial areas. Apart from screening out sunlight, dust on leaves blocks stomata and lowers their conductance to $\mathrm{CO}_{2}$, simultaneously interfering with photo system II. Air pollution is the presence of high concentration of contamination, dust, smokes etc., in the general body of air man breaths. Dust is defined as particulate matter as "any airborne finely divided solid or liquid material with a diameter smaller than 100 micrometers." Dust and smoke are the two major components of particulate matter. Car emissions, chemicals from factories, dust, and pollen and mold spores may be suspended as particles. Ozone, a gas, is a major part of air pollution in cities. When ozone forms air pollution, it's also called smog. These materials come from various sources, such as, various industrial processes, paved and unpaved roadways, construction and demolition sites, parking lots, storage piles, handling and transfer of materials, and open areas. Some air pollutants are poisonous. Inhaling them can increase the chances of health problems. In fact, dust when inhaled can increase breathing problems, damage lung tissue, and aggravate existing health problems. In addition to health concerns, dust generated from various activities can reduce visibility, resulting in accidents. Therefore, every federal Government should have stringent regulations which require prevention, reduction and/or mitigation of dust emissions. ${ }^{49}$

\section{Conclusion}

Various foliar types in plants exhibit differences; stickier leaves perform better in collecting more air-borne particles; some leaves possess greater surface stiffness and coarseness, which concern their adhesiveness for the particulates. The morphological feature of the leaf is a determinant factor for the crown area. Selection of tree species along the roadside needs to address the followings issues, viz. agro-climatic suitability, height and spread-area of the tree, canopy architecture, growth rate, straight undivided trunk, foliage pattern, attractive flower or inflorescence, tolerance to pollution and dust scavenging ability. In relation to the present scenario of urban environmental pollution, there is a research need for changing the approach of planting trees and other species. Ornamental trees/plants having pollution-mitigating capacity will better serve the purpose in beautification as well as combating air-pollution.

\section{Acknowledgments}

None.

\section{Conflict of interest}

The author declares no conflict of interest.

\section{References}

1. Grantz DA, Garner JHB, Jhonson DW. Ecological effects of particular matter. Environment International. 2003;29(2-3):213-239.

2. Das TM. Monitoring and control of air pollutants through plants. In: Ray M, et al, editors. Recent research in Ecology and pollution. Today's and Tomorrow's Printers and Publishers, India; 1980. p. 143-151.

3. Butz EL. Plants that will withstand pollution and reduce it. Health Guidance for Better Health. 2017.

4. Agrawal S, Tiwari S. Observation on Kiln dust pollution in Patrapalli region, Raigarh (MP). Flora and Fauna. 1997;3:131-133.

5. Somasekhar RK, Ravikumar R, Ramesh AM. Impact of granite mining on some, plant species around quarries of Bangalore district. Poll Res. 1999; 18(4):445-451.

6. Singh RB. Monitoring of dust pollution by higher groups of plants around dust polluted habitats in Sonbhadra UP. Ind $J$ Environ and Ecoplan. 2000;3:163-166.

7. Chatson K, Doley D. Mineral particulates and vegetation: Effect of coal dust, overburden and fly ash on light interception and leaf temperature. Clean Air and Environment Quality. 2006;40(1):40-44.

8. Chattopadhyay SP. The leaf surface effects of air pollution on certain tree species in Calcutta. Adv Plant Sci. 1996;9:1-14. 
9. Vijaywargiya A, Pandey GP. Effect of cement dust pollution on soybean Physiological and biochemical. Ecol Env and Cons. 1996;2:143-145.

10. Gupta AK, Mishra RM. Effect of limekiln's air pollution on some plant species. Poll Res. 1994;13:1-9.

11. Darley EF. Studies on the effect of cement kiln dust on vegetation. J Air Pollut Contr Ass. 1966;16(3):145-150.

12. Borka G. Effect of cement kiln dust on Maize plant. Acta Agron Hung 1981;30:289-295.

13. Singh M, Rao DN. The influence of ozone and sulfur dioxide on Cicer arientum L. J Ind Bot Soc. 1982;61:51-58.

14. Auclari D. Effect of dust on photosynthesis. I-effect of cement dust and coal dust on photosynthesis of Spruce. Ann Sci for. 1976;33:247-255.

15. Singh P, Sthapak J. Reduction in Protein contents in few plants as indicators of air pollution. Poll Res. 1999;18:281-283.

16. Treshow M. Terrestrial plants and plant communities. In: Bell JNB, editor. Air Pollution and plant life. Wiley Publishers, USA; 2002. p. 223-236.

17. Gunamani T, Gurusamy R, Swamynathan K. Effect of dust pollution on the dermal appendages and anatomy of leaves in some herbaceous plants. J Swamy Boli Club. 1991;8(3-4):79-85.

18. Pandey DD, Sinha CS, Tiwari MG. Impact of coal dust pollution on biomass, chlorophyll, nutrients and grain characteristics of wheat. $J$ Ecobio. 1992;4:19-22.

19. Pandey DD, Sinha CS, Mishra CP, et al. Response of soils of agro ecosystem to coal; dust pollution. Env Eco. 1992;10:389-390.

20. Griffths H. Effect air pollution on agricultural crops. Ministry of Agriculture, Food and rural Affairs, Ontario. Factsheet Order No. 85002, Canada; 2003.

21. Singh L, Siddiqui ZA. Effect of Alternaria triticina and foliar flyash deposition on growth, yield photosynthetic pigment, proteins and lysine contents of three cultivars of wheat. Bioresour Technol. 2003;86(2):189192

22. Naik DP, Ushamani, Somasekhar RK. Reduction in protein and chlorophyll contents in some plant species due to some stone quarrying activity. Environ Polln Cont J. 2005;8:42-44

23. Heerden PDR, Kruger GHJ, Louw MK. Dynamic Response of Photo system II in the Nalimb Desert shrub, Zygophyllum prismatocarpum, during and after foliar deposition of lime stone dust. Environmental pollution. 2007;146(1):34-45.

24. Krishna JR. Effect of coal dust pollution on the vegetation around Dhanbad Coalfield. Bio Journal. 1999;11:59-61.

25. Vijaywargiya A, Pandey GP. Effect of cement dust on soybean, Glycine $\max (\mathrm{L})$ merr. And Maize, Zea mays Linn. Inflorescence study. Geobios. 2003;30:209-212.

26. Yunus M, Ahmed KJ. Use of epidermal traits of plants in pollution monitoring. National Seminar on Environmental Pollution: A Status Review. National Productivity Council, India; 1979. p. 1-10.

27. Jafri S, Srivastava K, Ahmad KJ. Environmental pollution and epiderma structure in syzygium cuminii (L.) Ind J Air Poll Control. 1979;2:74-77.

28. Pal A, Kulshreshtha K, Ahmad KJ, et al. Changes in leaf surface structures of two avenue tree species caused by auto exhaust pollution. $J$ Environ Biol. 2000;21(1):15-21.
29. Garg SS, Kumar N, Das G. Effect of the Bansal Ramraj mill dust on vegetation and health at Jaitwara, District Satna. Indian Journal of Environmental Protection. 1999;20:326-328.

30. Shanmughavel P. Effect of air pollution of tobacco (Nicotiana tobacum) in agricultural fields. Eco Env Conser. 1997;2:173-174.

31. Prasad MSV, Inamdar JA. Effect of cement kiln dust pollution on plant of Psadium guajava. Ind J Env Health. 1990;22:231-237.

32. Chu TM, Aspinall D, Paleg LG. Stress metabolism: Salinity and proline accumulation in Barley. Aust J Plant Physiol. 1976;3:503-511.

33. Barnett NM, Naylor AW. Amino acid and protein metabolism in Bermuda grass during water stress. Plant Physiol. 1966;41(7):1222-1230.

34. Joshi VN, Arora SK, Luthra YP. Sulfur dioxide induced changes in CO fixation and photosynthetic pigments in sorghum (Sorghum bicolor L.) leaves. Annual Biology. 1993;9:102-108.

35. Hirano T, Kiyota M, Aiga I. Physical effects of dust on leaf physiology of cucumber and kidney bean plants. Environ Pollut. 1995;89(3):255-261.

36. Chaurasia B, Mahajan S, Chauhan SVS. Impact of automobile pollution on phenology and reproductive biology of Cassia siamea. Lam. Indian J Environ Sci. 2002;6:85-90.

37. Srinivas N, Chandrapaul B, Rao P. Biomonitoring of dust pollution. Nature Env Polln Techno. 2002;1:27-30.

38. Aftab A, Sakil A. Study of sulfur accumulation on plant foliage due to coal smoke pollution. Geobios. 2003;30(4):284-285.

39. Panichev N, Crindle Mc. The application of bioindicators for assessment of air pollution. J Environ Monit. 2004;6(2):121-123.

40. Singh RB. Monitoring of dust pollution by higher groups of plants around dust polluted habitats in Sonbhadra, UP. Ind $J$ Environ and Ecoplan. 2000;3:163-166.

41. Kulshrestha A, Dixit CK, Verma S, et al. Evaluation of some air pollution tolerant plants in Agra city. Indian J Environ Protect. 2003;23:805-808.

42. Beckett KP, Freer Smith PH, Taylor G. Urban Woodlands: Their role in reducing the effects of particulate pollution. Environ Pollut. 1998;99(3):347-360.

43. Choudri PR, Gajghate DG. Assessment of air pollution effects on plants: A review. Indian J Environ Protect. 2000;20:925-933.

44. Kumar RR, Sharma D. Impact of stone crusher dust on leaves of Mangifra indica L. and Psidium guajava L. in Jammu. J Env Zoo. 2001;15:75-79.

45. Rangarajan TN, Arjun MC, Ponnammal NR. Effect of automobile pollution on few ornamental plants. Eco Env Conserv. 1995;1:1-6.

46. Emberson LD, Ashmore MR, Murray F, et al. Impacts of air pollution on vegetation in developing countries. Water, Air and Soil Pollution. 2001;130(1-4):107-118

47. Kaushik GC. Cytotoxicity of cement kiln dust on mitosis of root tip cells in Vicia faba. J Ecotoxico Environ Monit. 1996;6(1):53-57.

48. Kumar SR, Arumugam T, Anandakumar CR, et al. Use of plant species in controlling environmental pollution-A review. Bulletin of Environment Pharmacology and Life Sciences. 2013;2:52-63.

49. Pandey $\mathrm{PC}$, Jain DK. Effect of $\mathrm{SO}_{2}$ and $\mathrm{NO}_{2}$ pollution on the growth of puum satgrum. Acta Botanica Ind. 1991;19:123-125. 